\title{
Using the Problem-Based Learning in STEM Teaching About Bamboo Toothpick Houses
}

\author{
Ngoc-Giang Nguyen ${ }^{1}$ \\ ${ }^{1}$ Banking University of Ho Chi Minh City, Ho Chi Minh City, Vietnam \\ Correspondence: Ngoc-Giang Nguyen, Banking University of Ho Chi Minh City, Nguyen Thai Binh ward, district \\ 1, Ho Chi Minh City, Vietnam. E-mail: nguyenngocgiang.net@gmail.com
}

Received: April 14, 2020

doi:10.5539/ies.v13n12p70
Accepted: May 21, $2020 \quad$ Online Published: November 28, 2020

URL: https://doi.org/10.5539/ies.v13n12p70

\begin{abstract}
In Vietnam, there are currently stable and comprehensive innovations in the field of education. Educational scientists have shifted from knowledge-focused teaching to competency teaching. Since then, there have been more new research directions in teaching than in the past, such as integrated teaching, practical application of mathematics and STEM teaching, etc. In these directions, STEM teaching is a new and broad topic. In particular, there are many teaching methods used in STEM teaching. Some people use project teaching, some use discovery teaching, and some others use cooperative teaching methods. Through the research process, we found that STEM is an integrated area, so we should choose one of the most appropriate ways to approach it. That is a problem-based learning method. How does STEM teaching work with problem-based learning? To illustrate this STEM teaching work, we will use the design and implementation of the model of a bamboo toothpick house at Ho Chi Minh City International College.
\end{abstract}

Keywords: STEM education, design, implementation, lighting, the model of bamboo toothpick houses

\section{Introduction}

The technology revolution 4.0 has been happening fast based on the integration of many science and technology fields together. From digital connectivity to the Internet of Things artificial intelligence, nanotechnology, biotechnology, nanomaterials to self-driving cars, the world, including Vietnam, has wholly changed production and consumption. The Vietnamese Government is aware of the opportunities and limitations that the technology revolution 4.0 brings. Vietnam is currently taking shortcuts and welcoming advanced technologies in the world. Not only does Vietnam compete with one country or a group of countries, but it also competes globally. To compete in such a large playing field, it is nothing more than to promote further the field of science and technology, specifically here in the area of STEM. STEM stands for S: Science; T: Technology; E: Engineering and M: Math. STEM education equips learners with applied knowledge, enhances their ability to detect, solve problems, and develop creative competency. In Vietnam, there are currently robust and comprehensive innovations in the field of education. We found that STEM is an integrated area, so we should choose one of the most appropriate methods to approach it. That is a problem-based learning method. How does STEM teaching work with problem-based learning? To illustrate this STEM teaching work, we will use the design and implementation of the model of a bamboo toothpick house.

STEM education makes students realize that the sciences are not academic (it means that they have not any applications in real-world), but useful and worth learning. However, in Vietnam, the STEM field is entirely new. They mainly train teachers in the academic direction, so it is challenging to explore STEM-oriented teaching. Vietnam has not had any teachers who have been well trained in STEM and have graduated to serve to teach. Therefore, STEM education is inherently more difficult.

Currently, there are many types of research on STEM teaching in the world. For example, Yldiz et al. (2015) evaluated STEM education studies in math and science from 2010-2015. Yldirim and Topalcengiz (2018) developed the STEM Pedagogical Content Knowledge Scale (STEMPCK Scale). Stephanie \& Erin (2019) showed the skills needed by a student to graduate from a career based on STEM. How do some high schools succeed in STEM teaching? The authors also point out the necessary skills in the XXI century when teaching STEM. Reynders et al. (2020) used Rubrics in assessing critical thinking and information processing in STEM teaching universities. Rubrics help teachers assess students' STEM skills, thereby helping students learn better. Students are 
more interested in learning STEM. Allen et al. discussed the quality of the STEM program, the relationship between the quality and output of college graduates in the United States. Hallström and Schonborn (2019) think that, when studying STEM, the integration of subjects must go along with maintaining the integrity of the issues. STEM is the bridge between theory and practice.

Kurup et al. (2019) said that STEM education should start in elementary schools and should actively involve young people in their future. To create a generation of interest and skills in STEM, teachers should get students to work together in an integrated approach. Teachers play an essential role in STEM education. Teachers both play the role of instructor and act as learners with students. Margot and Kettler (2019) also agreed with Kurup et al. (2019) when considering STEM teaching schools. It is important to train teachers who are both excellent at pedagogical methods and professional knowledge. Teachers play an essential role in the talent development process, helping students develop practical skills in STEM teaching. Meanwhile, Omkin et al. (2019) wrote, when teaching STEM, it is necessary to be learner-centered, fostering, and developing positive thinking for students.

Seyranian et al. (2018) studied gender and found that there is a big gap between men and women in STEM teaching. Female students are often less than male students in STEM-related professions. Manly et al. (2018) also stated that gender influences student learning at universities. Typically, female students in non-STEM schools are more likely to graduate than female students enrolled in STEM schools.

In Vietnam, some domestic researchers specializing in STEM research have also initially achieved specific results. Nguyen et al. (2017) devised a process of designing STEM education topics, including five steps: Practical issues $\rightarrow$ STEM concept ideas $\rightarrow$ Identify STEM knowledge to solve $\rightarrow$ Define STEM topic goals $\rightarrow$ Develop STEM topic-oriented questionnaires. The authors also use project-based teaching as the only teaching method in STEM education. Le (2017) introduced a 5-step process of developing STEM topics: Select specific content in the subject $\rightarrow$ Connect with products and items in practice $\rightarrow$ Application analysis $\rightarrow$ Point out relevant knowledge in issues in the field of STEM $\rightarrow$ Topic formation. Tran et al. (2018) dealt with the interaction between fields in STEM education and the process of designing STEM education topics in teaching biology with six steps as follows. First, select STEM education topics. Second, identify the goals of the STEM education topic. Third, identify issues to be addressed in the STEM education topic. Fourth, identify specific problems to be used to solve problems in STEM topics. Fifth, design activities. Finally, design criteria and testing tools, student assessment, etc.

Many authors have studied about problem-based learning. Nguyen and Tran (2019) offered a process of problem-based learning as well as illustrative examples of electrical diagrams. The authors also point out the advantages and disadvantages of problem-based learning in teaching students in technical schools. Ho (2017) presented a survey that the method of problem-based learning helps students in many ways. It will help them be active in learning, form the need to solve learning tasks, stimulate curiosity, be passionate about exploring science, make students motivated to develop, and foster creativity, collaboration, and critical ability. Hmelo-Silver (2004) provided the cycle table of problem-based learning cycle as well as comparing project-based teaching and problem-solving teaching. Strobel and Van Barneveld (2009) mentioned some perspectives on problem-based learning and how it helps, etc.

Although there have been many pieces of research on STEM and problem-based learning, there have not been any research projects on problem-based learning on STEM bamboo toothpick houses. Therefore, in this article, we will show how to use the method of problem-based learning in STEM teaching on the topic of designing, implementing, and lighting electricity for the model of bamboo toothpick houses in Vietnam.

We now go to problem-based learning, the role of STEM teaching in schools, the interaction between areas of STEM teaching, and the process for problem-based learning of STEM topic problems.

\section{Method}

\subsection{Problem-Based Learning Method}

There are many views on problem-based learning. According to Nguyen (2004), in problem-based learning, teachers create problem-solving situations, tell students to detect problems, act voluntarily, positively, proactively and creatively to solve the issues and thereby build knowledge, train skills, and achieve other learning goals. Pham (2011) wrote that problem-solving methods are teaching methods in which teachers create problem-solving situations and students through problem-solving learning activities, create new knowledge, train skills, and achieve teaching goals. A problematic situation is one that evokes students with theoretical or practical difficulties that they feel are capable of overcoming, but not immediately but undergoing a positive process of thinking, working to transform objects, or adjusting existing knowledge.

The role of STEM teaching in schools now is significant. The education of Vietnam interests in this topic very 
much.

\subsection{The Role of STEM Teaching in Schools}

Nguyen et al. (2018) said that STEM teaching would bring many benefits. Specifically:

Ensuring comprehensive education: Deploying STEM education in schools, besides subjects such as Math and Science, Technology, and Engineering fields, will also be considered and invested in all aspects (teachers, programs, facilities).

Increasing interest in learning STEM subjects: Learning projects in STEM education aim to apply interdisciplinary knowledge to solve practical problems. Students act, experience, and see the meaning of wisdom in their life, thereby increasing their interest in learning.

Forming and developing competency and quality for students: When implementing STEM learning projects, students cooperate proactively and self-implement the learning tasks; be familiar with activities of a scientific research nature. The activities, as mentioned above, contribute positively to the formation and development of qualities and competencies for students.

Connecting schools with the community: To ensure effective implementation of STEM education, the general education institution usually connects with local vocational schools and universities to exploit human resources and facilities to implement STEM educational activities. Besides, STEM education in high schools also aims to solve typical local issues.

Career guidance and streaming: Well-organized STEM education in high school, students will experience in STEM fields, assess their suitability, aptitude, and interests in careers in the field of STEM. It is also a way to attract students to study, select professions in the field of STEM, which is in high demand for human resources in the 4 th industrial revolution.

This part refers to the integrated things in STEM teaching.

\subsection{Interaction Between Areas of STEM Teaching}

According to Thornburg (2008) and Tran et al. (2018), the fields of science, technology, engineering, and mathematics are closely related to STEM teaching. Math and technology are used in scientific and technical research to help people explore and improve the world. In contrast, Science and Technology promote the advancement of Mathematics and Technology. The difference between Science and Technology shows the purpose and method of implementation. The goal of science is to "search" for the study of things and natural phenomena, and technology is about the "implementation" to design and manufacture objects for the advancement of humanity. Scientists use a "Scientific Method" to explore nature and make assumptions and verifications that are formed and developed for students at multiple grade levels. To design and manufacture, engineering needs to build and develop for students' creativity and innovation, which are essential attributes in the field of engineering but difficult to quantify and take a long time to form. A prolonged learning environment stimulates creativity. This difference is relative because science also requires creativity, and engineering studies also need scientific methods. Therefore, the approach to STEM education must be an interdisciplinary approach to create a harmonious combination between the fields of Science, Technology, Engineering, and Mathematics to help students experience reality to explore knowledge and create meaningful products.

We now go to the process of problem-based learning of STEM teaching. This process includes eight steps.

\subsection{The Process for Problem-Based Learning of STEM Topic Problems}

\section{Step 1. Detecting STEM topics}

STEM topics for teaching can come from teachers, students, or external factors. During the teaching process, if teachers find the STEM topics interesting, practical, or those topics have a pedagogical effect, stimulate exploration, teachers can assign tasks to students to design and learn those STEM topics. Teachers do not have to impose students to work the STEM topics, but teachers should inspire them to be attracted to the subject given. Teachers must turn external learning motivation into a student's internal learning motivation.

Step 2. Identify problem-based learning methods that are appropriate on STEM topics

Depending on the students' qualifications, competence, and attitudes, teachers have appropriate forms of problem-based learning. If the student is good and patient, the teacher should use the gradually permeable teaching method (Osmosis). Students are "immersed" in the environment on the subject of STEM to address. Students are encouraged to solve the STEM topic with all their efforts, not being pressured by time, not afraid to fail. They are allowed to choose how to do and complete their STEM topics. 
If students are weak, they will receive a lot of support from teachers. Memorization teaching should be applied to the students. STEM topic-solving tasks are broken down by teachers into small learning doses that students can comfortably handle. Students then memorize and summarize the jobs they have completed.

If the students are outward-oriented, we should assign them to work in groups. They are allowed to discuss and argue their decisions with their peers, thus finding the best way to solve STEM topics.

If the class has many students with different minds and strengths, the teacher can divide the teaching of STEM into doses that are appropriate to the tendency of each group of students or each student. Then sum up the results together. This teaching method is a reflection method. This teaching method assumes that students learn by working and reflecting on what they do. Students are encouraged to restate how to solve their problems.

Step 3. Select materials and learning media in teaching STEM topics

Teachers ask students to prepare materials for STEM learning. Where do these materials come from? Where to buy? What are the accompanying tools? What is the learning media to prepare?

Step 4. Determine the knowledge of STEM students need to prepare

Teachers hand over STEM learning materials for students to prepare in advance. What is the basic knowledge of STEM topics? What is the knowledge to learn about science, technology, engineering, and math? What knowledge can be read and understood? What knowledge goes beyond the program to receive to complete STEM products?

Step 5. Set goals when teaching STEM topics

Teachers should know the knowledge, skills, attitudes, and competencies that students achieve after completing the STEM product. In terms of knowledge, teachers should classify into three categories. The first type is the knowledge that students have learned; the second type is new knowledge, but students can read and understand themselves; the third type is new knowledge, but students do not understand. It is outside the student's curriculum. This type of knowledge students should accept the results to apply. When teaching STEM lessons, the teacher needs to determine how well the students are performing, so the requirement of a student's training will be met. Students with weak and moderate academic performance should focus on fostering knowledge, understanding, and application activities; Students who have good and excellent academic ability promote analytical, evaluating, and creative teaching activities.

In terms of skills, teachers need to identify which skills students will learn through the STEM topic. What are thinking skills? What are the scientific skills? What are the learning skills?

In terms of attitude, teachers ask students to be positive, passionate about science, conscious of environmental protection, conscious of recycling waste products in life. In studying, they should never stop learning. If they decide to do something, they should work till the end.

In terms of competency, teachers focus on training some key competencies such as problem-solving, creative thinking, cooperative, and artistic skills.

Step 6. Design lessons of STEM topic

After defining the lesson objectives, the teacher should write a detailed lesson plan on how to teach STEM. The primary teaching method here is the problem-based learning method. The teacher creates a detailed questionnaire that corresponds to the task that the student needs to complete in STEM learning. What is the question when a student is about to start studying? How to design STEM products? How to perfect the STEM product? What is the way to use learning media in the teaching process? Do we need dosage more or less? For how well the student learns, the question must correspond to the student's level of awareness. The design of STEM products assigned to each child or group motivates them to collaborate and know how to work collectively.

Step 7. Design a toolkit, criteria for testing and evaluating students

To evaluate students' products and cooperation in learning activities (if any), teachers need to design learning assessment sheets, distribute appropriate scores for each indicator. Design evaluation sheets for group activities, build evaluation criteria, distribute points appropriately for each sign, and complete the evaluation form.

Step 8. Find out more about the STEM topic

From teaching STEM topics, teachers encourage students to learn more about other STEM products with similar design methods, benefits of studying STEM topics, difficulties that they need to overcome. Students can dig deep, develop more about the features of the STEM products they have done as well as draw the results achieved after learning. 
This part illustrates the example of the topic of designing and implementing a model of bamboo toothpick houses in Vietnam.

\section{Results}

\section{Step 1. Detect STEM topics}

Bamboo is a popular product in Vietnam. Bamboo is the forest product behind wood and can replace wood in many areas. Currently, the situation of logging is increasingly exhausted in Vietnam, and bamboo will be a popular material in the future. Bamboo toothpicks are universal tools for Vietnamese people. People use toothpicks to floss their teeth. However, bamboo toothpicks are also raw materials for processing fine arts models such as bamboo toothpick houses.

Construction and architecture are an essential group of the economy, tasked with leading the way in national construction and development. It is a group that needs a harmonious combination of arts and technology. It aims to create a beautiful, quality, convenient, functional, and livable place to live, creating a comfortable, modern living environment.

The topic "Designing and implementing a model of bamboo houses" helps students understand the process of forming a construction project from the formation of design ideas to the completion of a house. Through this topic, students can also learn and apply general knowledge to practical work, helping students develop creative thinking and career orientation for students.

Step 2. Identify problem-based learning methods that are appropriate on STEM topics

Teachers use the problem-based learning method of osmosis type and in combination with cooperation to help students design a model of a bamboo house. Students with good spatial thinking will cooperate with ingenious and meticulous students. This STEM topic is both familiar and exciting, so students actively participate in the direction of the teacher.

Step 3. Select materials and learning media in teaching STEM topics

Materials and tools needed:

+ Pebbles;

+ Toothpicks, round wooden sticks;

+ Flat ice cream sticks;

+ Scissors (steel blade);

+ Small hand saws;

+502 glue;

+ Garden plants and flowers;

+ Paint;

+ Some other auxiliary tools: knives, scissors, pencils, A3, A4 paper, etc.

Regarding learning media, there are lights, computers connected to the Internet, etc.

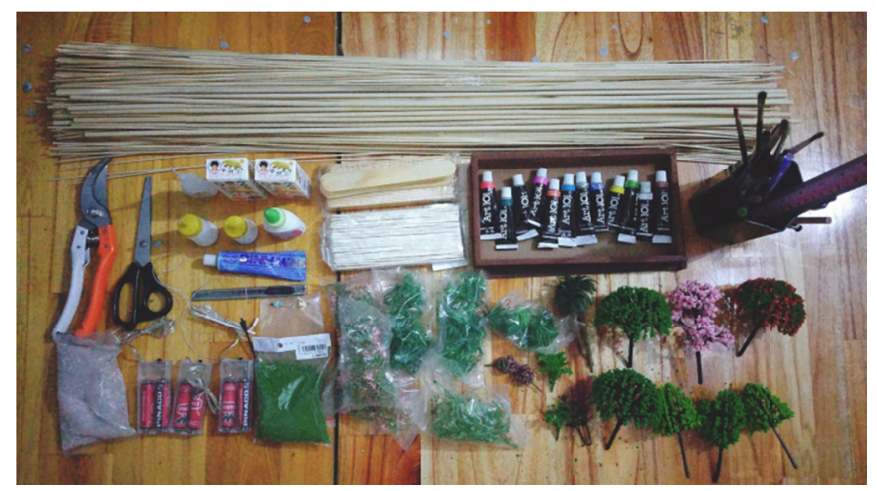

Figure 1. Materials for designing bamboo toothpick houses, Vietnam, 2020 (Personal collection) 
Step 4. Determine the knowledge of STEM students need to prepare

Basic knowledge:

+ Physical concepts: gravity, focus, etc.;

+ Basic geometric knowledge, calculating the rate of the drawing;

+ Fine arts: A suitable color combination;

+ Stating the concept of architecture types and showing students some pictures about house architecture;

+ Some basic architectural principles;

Knowledge of design plans:

+ Students use a pencil to sketch their ideas on paper (about the shape and size of the house and garden);

+ The teacher corrects the plan so that it is complete and suitable for the model.

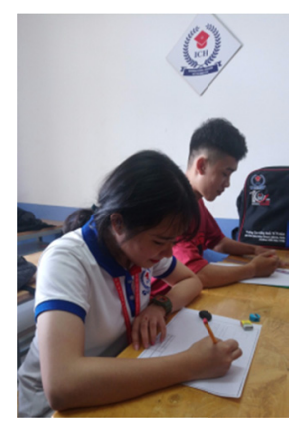

Figure 2. A female student of $9+$ College program - Ho Chi Minh City International College is learning how to design a bamboo toothpick house, Vietnam, 2020 (Personal collection)

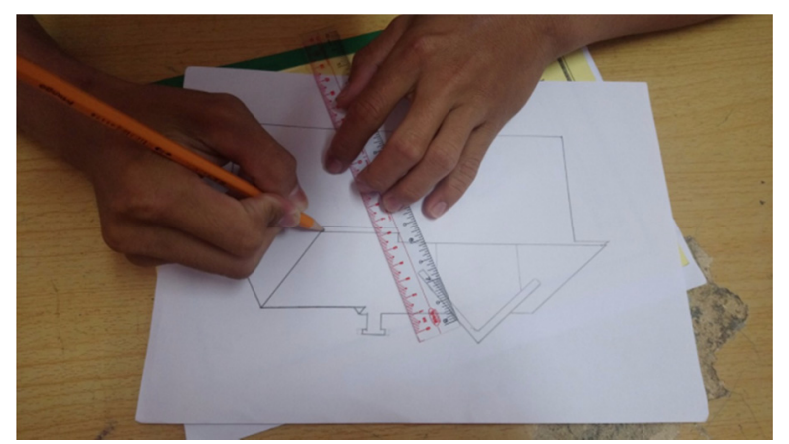

Figure 4. A student of 9+ College program - Ho Chi Minh City International College is designing a bamboo toothpick house, Vietnam, 2020 (Personal collection)

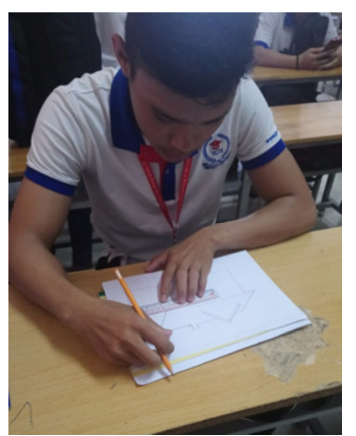

Figure 3. A male student of 9+ College program - Ho Chi Minh City International College is learning how to design a bamboo toothpick house, Vietnam, 2020 (Personal collection)

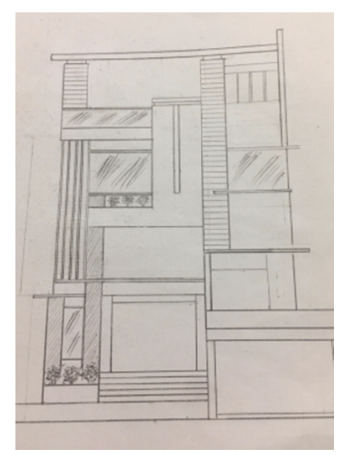

Figure 5. A complete plan of a bamboo toothpick house, Vietnam, 2020 (Personal collection)

Step 5. Set goals when teaching STEM topics

\section{Knowledge}

Applying common knowledge of physics, mathematics, fine arts to the reality of construction and architectural work. Integrating physical, mathematical, and technological knowledge and techniques to design and implement bamboo toothpick house models.

Skills

Communication skills and teamwork collaboration;

Being able to explain the process of implementing model houses and building houses in practice; 
Promoting creativity and logical thinking when drawing the plan manually according to ideas and implementing models;

Critical thinking and problem-solving skills

Attitude

Having a spirit of cooperation and a sense of responsibility;

Be careful and meticulous in the process of implementing individual details.

Table 1. STEM table

\begin{tabular}{cl}
\hline STEM skills & \multicolumn{1}{c}{ Application knowledge } \\
\hline SCIENCE & Linking physical concepts (gravity, focus), mathematical knowledge (calculating the length and height of details, \\
(S) & geometry), fine arts, etc. to make the plan of the model and make models. \\
\hline TECHNOLOGY & - Using pencils, rulers, A4 paper (A3), you can use a computer to implement the design concept. \\
(T) & - Use tools such as pliers, scissors to make the model. \\
\hline ENGINEERING & - Students understand the process of model implementation as well as the process of building a home. \\
(E) & - Directly generate ideas, directly implement models from analysis, synthesis and combination to balance physical, artistic \\
aATHEMATICS & $\begin{array}{l}\text { Calculate the rate, the balance between the objects of the model. } \\
\text { (M) }\end{array}$ \\
Calculate and measure models from plans to reality.
\end{tabular}

Step 6. Design a lesson for STEM topics

+ Duration: time for implementation of 20 periods/class or more (30 to 40 students)

+ Location: Classroom or practice room of the school or student's house.

+ Implementation process:

Table 2. Design a lesson for STEM topics

\begin{tabular}{|c|c|c|}
\hline Content & Teacher's activities & Students' activities \\
\hline \multicolumn{3}{|c|}{ Step 6.1. Planning (working in class -5 periods) } \\
\hline $\begin{array}{l}\text { Name the STEM topic you } \\
\text { need to learn }\end{array}$ & $\begin{array}{l}\text { Point out a problematic situation in need } \\
\text { of designing bamboo toothpick models } \\
\text { in Vietnam. }\end{array}$ & $\begin{array}{l}\text { Get to know the topic, learn more about bamboo, and about some } \\
\text { architectural knowledge. }\end{array}$ \\
\hline $\begin{array}{l}\text { Develop design ideas and } \\
\text { implement STEM topics }\end{array}$ & $\begin{array}{l}\text { - Divide into groups of } 3 \text { to } 5 \text { students; } \\
\text { - Subjects: students in grades } 8 \text { to 12; } \\
\text { - Help students develop ideas; } \\
\text { - Agree on a single idea. }\end{array}$ & Group activities, sharing, planning to implement ideas. \\
\hline $\begin{array}{l}\text { Planning the } \\
\text { implementation of STEM } \\
\text { topics }\end{array}$ & $\begin{array}{l}\text { - Ask students to state the tasks that } \\
\text { need to be done with the STEM topic; } \\
\text { - Teachers suggest with guiding } \\
\text { questions: } \\
\text { + In processing handicrafts, is bamboo } \\
\text { important or not? } \\
\text { + In construction, what is the benefit of } \\
\text { house design? } \\
+ \text { Why is it necessary to design and } \\
\text { implement a model of bamboo toothpick } \\
\text { houses in Vietnam? } \\
\text { From these orientation questions, } \\
\text { suggest students the task to be } \\
\text { performed. } \\
\text { - Teachers hand out evaluation sheets; } \\
\text { product reviews, performance } \\
\text { assessments for students. }\end{array}$ & $\begin{array}{l}\text { - Based on the learning topic and suggestions of the teacher, students } \\
\text { propose and promote the tasks to be performed. } \\
\text { - Students assign tasks to each member of the group, the time of each } \\
\text { person, the method of implementation and the means to produce the } \\
\text { final product, a bamboo toothpick house. } \\
\text { - Design PowerPoint slides to report the work of the group. }\end{array}$ \\
\hline
\end{tabular}


Step 6.2. Implementation and construction of STEM products (10 periods) (after school hours)

Design a bamboo toothpick house model based on the design plans:

+ Put toothpicks and paste into pieces according to the dimensions on the project.

+ Use a ruler and pencil to paint the toothpicks according to the size of the drawing, then use a hand saw to saw the walls, roof, floor of the house.

+ Measuring and making doors, windows, and utensils, tools, garden such as tables, chairs, umbrellas in the right size and proportion of the plan

+ Mark and assemble parts from the bottom up.

+ Students can refer to documents about bamboo toothpick design.

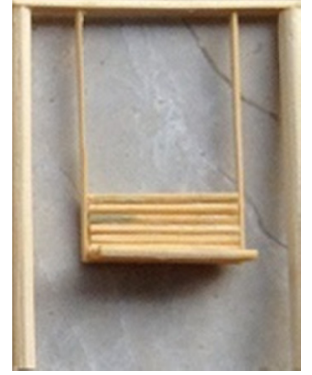

Figure 6. A student of 9+ College program - Ho Chi Minh City International College has designed a bamboo toothpick house, Vietnam, 2020 (Personal collection)

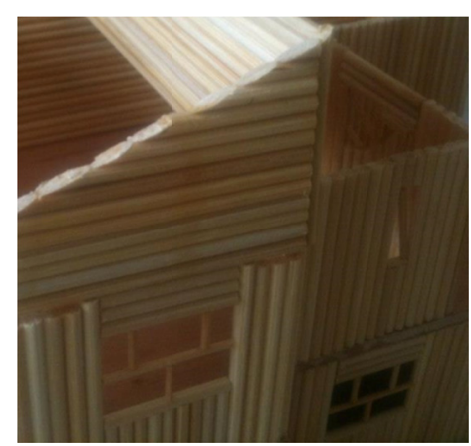

Figure 8. A student of 9+ College program - Ho Chi Minh City International College has designed a bamboo toothpick house, Vietnam, 2020 (Personal collection)

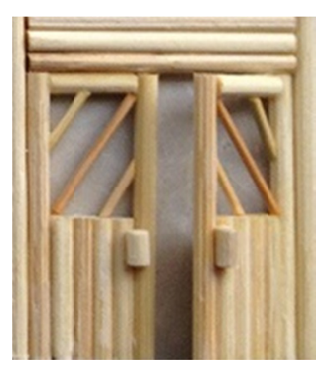

Figure 7. A student of $9+$ College program $-\mathrm{Ho}$ Chi Minh City International College has designed a bamboo toothpick house, Vietnam, 2020 (Personal collection)

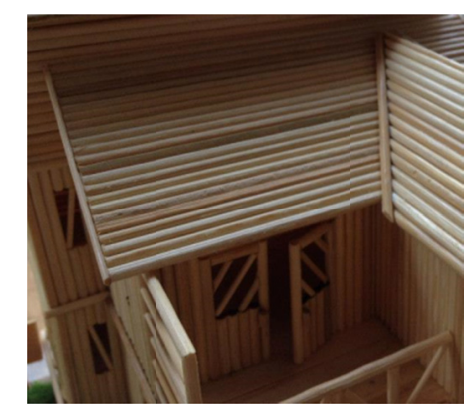

Figure 9. A student of 9+ College program $-\mathrm{Ho}$ Chi Minh City International College has designed a bamboo toothpick house, Vietnam, 2020 (Personal collection) 
Garden decoration:

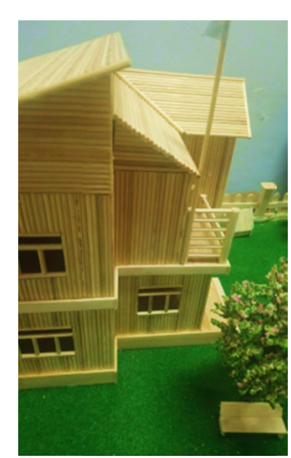

Figure 10. A student of 9+ College program - Ho Chi Minh City International College has decorated a bamboo toothpick house, Vietnam, 2020 (Personal collection)

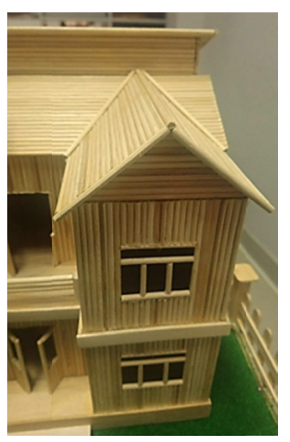

Figure 11. A student of 9+ College program - Ho Chi Minh City International College has decorated a bamboo toothpick house, Vietnam, 2020 (Personal collection)

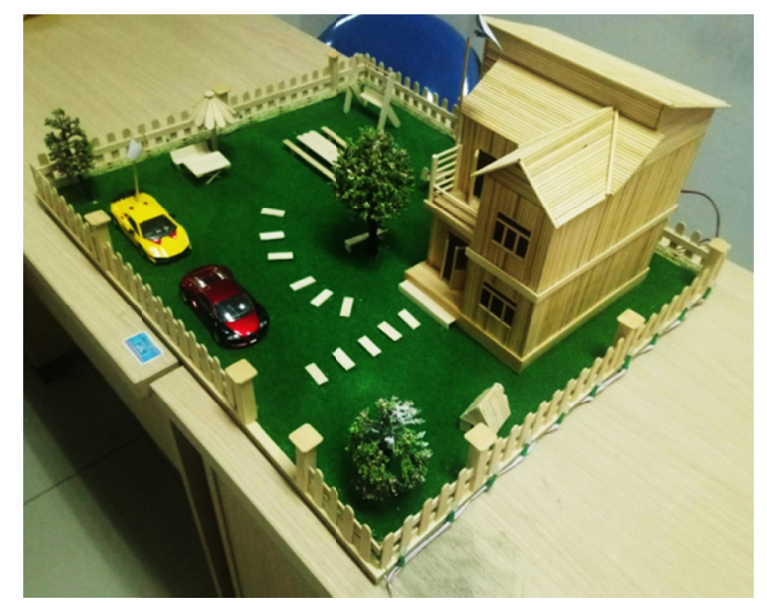

Figure 12. A student of 9+ College program - Ho Chi Minh City International College has decorated a bamboo toothpick house, Vietnam, 2020 (Personal collection)

Complete the report to prepare the product presentation:

- Students perfect the product;

- Write a description presenting the product: materials, how to make, how to operate the product, the applicability of the product;

- Instructors support students in the process of finishing products and preparing reports.

Table 3. Product presentation

\begin{tabular}{lll}
\hline Step 6.3. Reporting results (5 periods) & \\
\hline \multirow{2}{*}{$\begin{array}{l}\text { Reporting } \\
\text { results }\end{array}$} & - Organize groups for reporting results and feedback. & $\begin{array}{l}\text { - Groups report the results } \\
\text { - PowerPoint presentation }\end{array}$ \\
\hline \multirow{2}{*}{ Evaluation } & $\begin{array}{l}\text { Teachers guide students to self-assess and evaluate each other. The } \\
\text { teacher will then evaluate the students. }\end{array}$ & $\begin{array}{l}\text { Students use votes to self-assess and evaluate each } \\
\text { presentation of other groups. }\end{array}$ \\
\hline
\end{tabular}




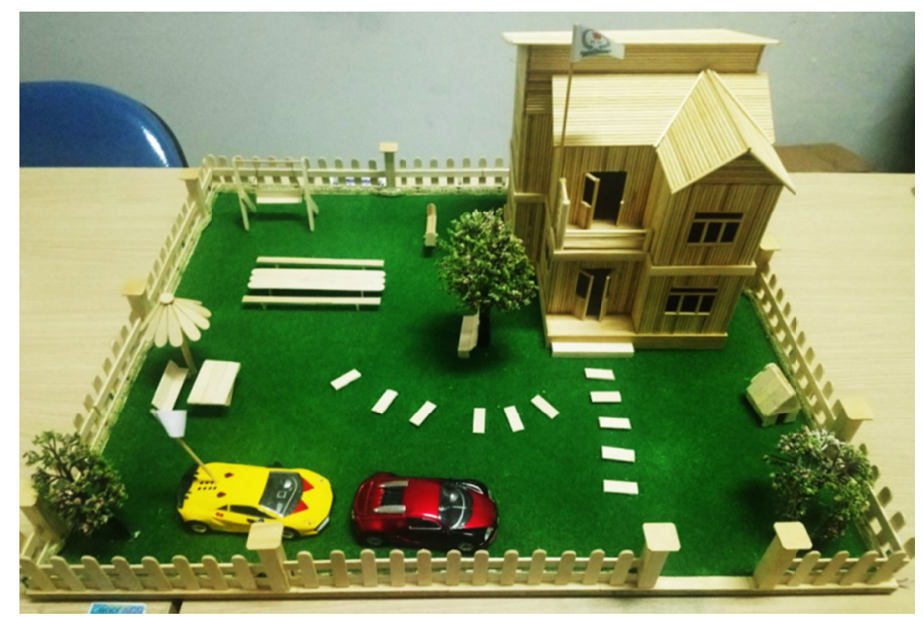

Figure 13. A complete bamboo house product, Vietnam, 2020 (Personal collection)

Step 7. Design toolkit, criteria for testing and evaluating students

In addition to the set of criteria for evaluating group and individual activities, we also develop a set of standards for assessing the model of a bamboo toothpick house model as follows:

Table 4. Criteria for testing and evaluating students

\begin{tabular}{llll}
\hline Criteria & Good (5 marks) & Fair (3 marks) & \multicolumn{2}{l}{ Poor (1 mark) } \\
\hline Form & $\begin{array}{l}\text { Reasonable model structure; installing } \\
\text { parts with appropriate proportions. }\end{array}$ & $\begin{array}{l}\text { Relatively appropriate model structure; } \\
\text { installing part in some places have } \\
\text { unreasonable ratios. }\end{array}$ & $\begin{array}{l}\text { Inappropriate } \\
\text { installation } \\
\text { inconsistent proportions. }\end{array}$ \\
\hline Firmness & Sure model. & The model is not very sure & Unsure model. \\
pesign & $\begin{array}{l}\text { Students have completed the product } \\
\text { according to the design plan. They can } \\
\text { plan } \\
\text { read the drawing. }\end{array}$ & $\begin{array}{l}\text { Completing a part of the product according to } \\
\text { the plan. Do not know how to read some } \\
\text { places on the drawing. }\end{array}$ & $\begin{array}{l}\text { Failed to finish the product } \\
\text { according to the plan. Failed to read } \\
\text { the drawing. }\end{array}$ \\
\hline Creativity & $\begin{array}{l}\text { Products are innovative, have high } \\
\text { practical applicability. }\end{array}$ & $\begin{array}{l}\text { Products that express creativity but are a bit } \\
\text { awkward. }\end{array}$ & $\begin{array}{l}\text { Products are still mouldy, not } \\
\text { flexible. }\end{array}$ \\
\hline
\end{tabular}

Some evaluation questions:

Question 1. When designing the model of a bamboo toothpick house, did you find that the parts of the bamboo toothpick house are reasonably designed? Is the main door smaller than the window?

Question 2. Is the bamboo toothpick house model sure? If it is not sure, what should you do to make a bamboo house model stronger?

Question 3. Looking at the model of a bamboo toothpick house, could you do the same to design the matchstick house model? And the model of ice cream stick house or not?

Question 4. Do you have any ideas to make the model of a bamboo house more lively, beautiful, and more aesthetic?

Question 5. In your opinion, what are the scientific, technological, technical, and mathematical factors in designing a bamboo toothpick house model? Please fill in the following form. 
Table 5. STEM table

\begin{tabular}{l|l}
\hline Full name: $\ldots \ldots \ldots \ldots \ldots \ldots \ldots \ldots \ldots \ldots \ldots \ldots . . \ldots$ \\
\hline SCIENCE $(\mathrm{S})$ & \\
\hline TECHNOLOGY (T) & \\
\hline ENGINEERING (E) & \\
\hline MATHEMATICS (M) & \\
\hline GENERAL CONCLUSIONS: & \\
\hline
\end{tabular}

\section{Step 8. Learn more about STEM topics}

After the design and implementation of the model of a bamboo toothpick house, teaching STEM topics is not yet finished. Teachers should ask students to find out more about the issue of STEM. After we design the bamboo toothpick house model, can we make the bamboo toothpick house more useful? Can the product be more artistic and valuable in real life?

To answer these questions, the teacher should suggest that students design and light up the model of a bamboo house.

Step 8.1. STEM topic discovery

The industrial and civil electricity sector is present in almost all areas of social life. The process of industrialization and modernization of our country now needs a lot of human resources for this industry. According to statistics on human resource needs, the electricity industry is always in the top 10 sectors with a significant labor shortage in Vietnam.

The topic "Designing and lighting electricity for house models" is a topic from practical needs and closeness to all students. The subject helps students understand the electrical installation process from design to implementation, see the application of learned knowledge to work, and general knowledge at school associated with daily life.

\section{Step 8.2. Identify problem-based learning methods that are appropriate on STEM topics}

Teachers use the problem-based learning method of gradually absorbing type (Osmosis) in combination with teaching cooperation to help students design a model of a bamboo house. Students with good spatial thinking will cooperate with ingenious and meticulous students. This STEM topic is both familiar and exciting, so students are actively involved in the teacher's instruction.

Step 8.3. Selection of materials, learning media in teaching STEM topics.

Materials and tools needed:

- Electric tools and equipment: Gauges of all kinds, electrical wire, led bulb, 9v power battery, switch, board, circuit, small welding machine, pliers, glue.

- Auxiliary materials: Electric tape, glue, scissors.

- A pencil, a ruler, A4 paper.

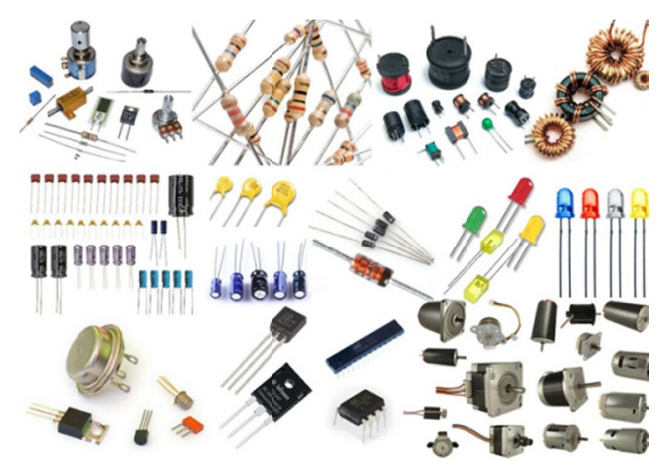

Figure 14. Materials for lighting bamboo toothpick houses, Vietnam, 2020 (Personal collection)

Step 8.4. Identify the knowledge of STEM that students need to prepare 
Teaching theoretical knowledge

+ Knowledge of physics: Concepts of conductors, resistors, amperage, power. Ohm's law, Jun-lens's law

+ Attention about electricity safety

+ Instructions for wiring, power sources, light bulbs.

+ Calculating and using resistors and power meter according to the drawing.

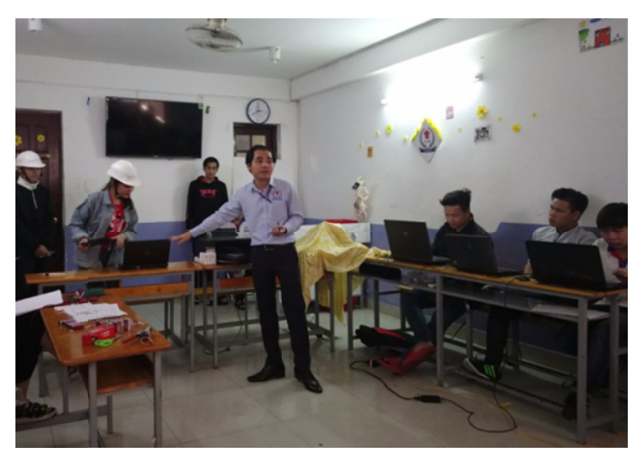

Figure 15. Teaching the students of $9+$ College program - Ho Chi Minh City International College how to read drawing symbols and use gauges, Vietnam, 2020 (Personal collection)

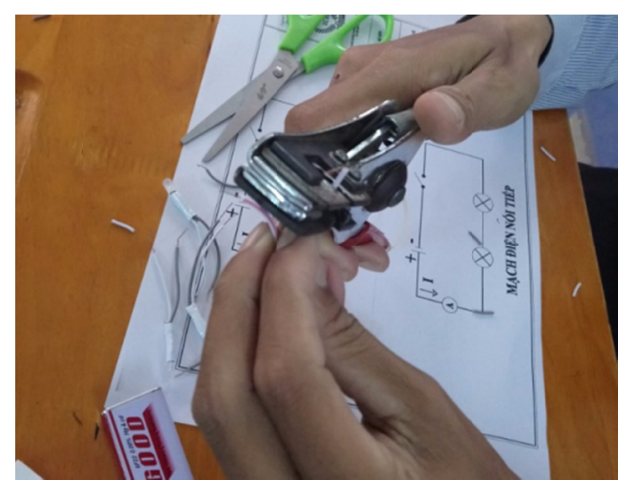

Figure 17. Teaching the students of 9+ College program - Ho Chi Minh City International College how to read drawing symbols and use gauges, Vietnam, 2020 (Personal collection)

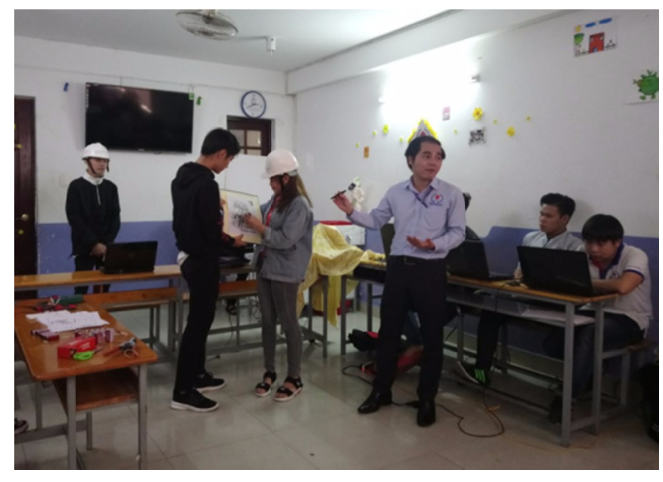

Figure 16. Teaching the students of 9+ College program Ho Chi Minh City International College how to read drawing symbols and use gauges, Vietnam, 2020 (Personal collection)

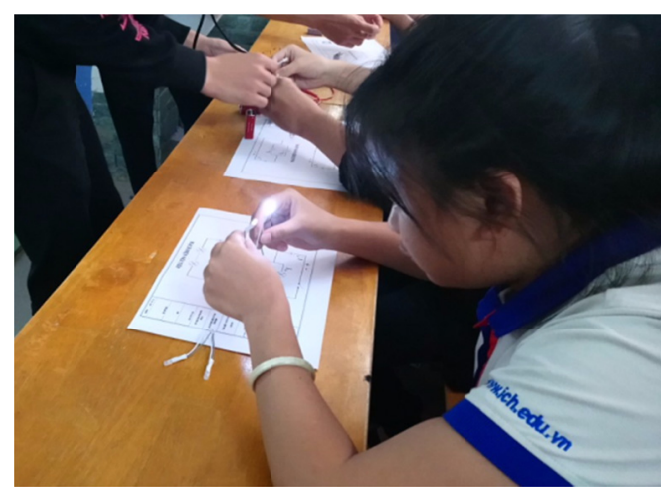

Figure 18. Teaching the students of 9+ College program Ho Chi Minh City International College how to read drawing symbols and use gauges, Vietnam, 2020 (Personal collection)

Instructions for designing electric drawings

+ Students use a pencil to draw simple electrical circuits (parallel circuits, series circuits) on A4 paper

+ Teachers can guide students to use Auto Cad software on computers to create electric circuit drawings 


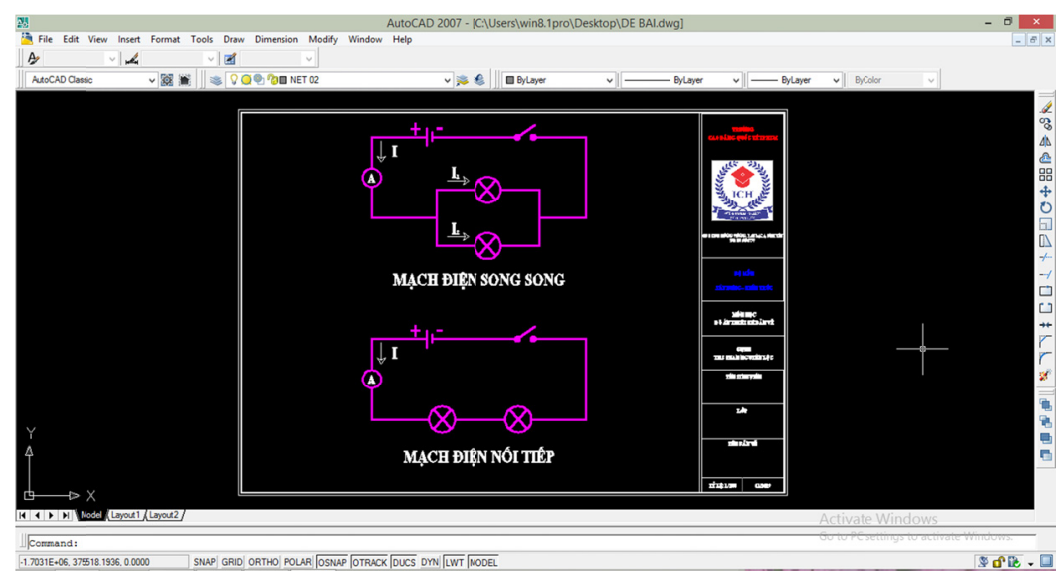

Figure 19. Electrical chart Vietnam, 2020 (Personal collection)

+ Teachers edit to perfect and fit the model.

Step 8.5. Define goals when teaching STEM topics

Knowledge

Students will be able to apply common knowledge of physics, general mathematics, and fine arts to reality in the electricity industry. Integrating physical, mathematical, and technological knowledge and techniques to design and light up electricity for house models.

Skills

Students will be able to exchange skills and teamwork collaboration.

Able to explain the process of installing electric lighting model of the house and installing electric lighting in reality.

Promote creativity and logical thinking when drawing electric circuit diagrams on paper and installing electric lighting for home models.

Critical thinking and problem-solving skills

\section{Attitude}

Students will have a spirit of cooperation and a sense of responsibility.

Strictly abide by electricity safety requirements.

Be careful and meticulous in the process of working.

Table 6. STEM table

\begin{tabular}{|c|c|}
\hline STEM skills & Application knowledge \\
\hline $\begin{array}{l}\text { SCIENCE } \\
\text { (S) }\end{array}$ & $\begin{array}{l}\text { Linking concepts, theorems, and formulas of universal physics } \\
\text { - Concepts of conductors, resistors, amperage, and power. } \\
\text { - Ohm's law, Jun-lens's law }\end{array}$ \\
\hline $\begin{array}{l}\text { TECHNOLOGY } \\
\text { (T) }\end{array}$ & $\begin{array}{l}\text { Accessing and using devices, software, and computers } \\
\text { - Electrical equipment: batteries, welding machines, power chips, boards, LEDs. } \\
\text { - Types of hand-held gauges. } \\
\text { - Auto Cad software drawing on the computer (teachers can instruct to use the software on the spot with simple circuits) }\end{array}$ \\
\hline $\begin{array}{l}\text { ENGINEERING } \\
\text { (E) }\end{array}$ & $\begin{array}{l}\text { Students can solve real-life problems, be able to make their products, and understand the process of building products. } \\
\text { - Students can connect the power cord from the source, catch light bulbs in reality. } \\
\text { - Students know how to make and can make their simple circuits. } \\
\text { - Use gauges when necessary on the actual electrical equipment at home. }\end{array}$ \\
\hline $\begin{array}{l}\text { MATHEMATICS } \\
\text { (M) }\end{array}$ & $\begin{array}{l}\text { Used in many stages } \\
\text { - From manual work such as calculating the length of wires and counting materials to calculating resistance, competency. } \\
\text { - Calculating the indicators on the meter. }\end{array}$ \\
\hline
\end{tabular}




\section{Step 8.6. Design a STEM topic lesson}

+ Duration: time for implementation of 20 periods/class or more (30 to 40 students)

+ Location: Classroom/practice room of the school or student's house.

+ Implementation process:

Table 7. Design a lesson for STEM topics

\begin{tabular}{|c|c|c|}
\hline Content & The teacher's activities & Students' activities \\
\hline \multicolumn{3}{|c|}{ Step 8.6.1. Planning (doing in class - 5 periods) } \\
\hline $\begin{array}{l}\text { Name the STEM topic } \\
\text { that students need to } \\
\text { learn. }\end{array}$ & $\begin{array}{l}\text { Describe the situation on the need to } \\
\text { design and light the model of a } \\
\text { bamboo toothpick house. }\end{array}$ & $\begin{array}{l}\text { Get to know the topic and learn more about electric lighting, the model of } \\
\text { a bamboo toothpick house. }\end{array}$ \\
\hline $\begin{array}{l}\text { Develop design ideas and } \\
\text { implement STEM topics }\end{array}$ & $\begin{array}{l}\text { - Divide into groups of } 3 \text { to } 5 \\
\text { students; } \\
\text { - Target audience: students from } \\
\text { grades } 8 \text { to 12; } \\
\text { - Help students develop ideas; } \\
\text { - Agree on a single plan. }\end{array}$ & Group activities, sharing, planning to implement ideas. \\
\hline $\begin{array}{l}\text { Planning the } \\
\text { implementation of STEM } \\
\text { topics }\end{array}$ & $\begin{array}{l}\text { - Ask students to state the tasks to do } \\
\text { with the STEM topic; } \\
\text { - Teachers suggest with guiding } \\
\text { questions: } \\
\text { + Is it essential to design and light } \\
\text { up a bamboo toothpick house? } \\
+ \text { In construction, how does } \\
\text { electrical design and lighting play? } \\
\text { These orientation questions suggest } \\
\text { students the tasks to perform. } \\
\text { - Teachers hand out evaluation } \\
\text { sheets, product reviews, and } \\
\text { performance assessments for } \\
\text { students. }\end{array}$ & $\begin{array}{l}\text { - Based on the learning topic and suggestions of the teacher, the student } \\
\text { proposes and promotes the tasks to perform. } \\
\text { - Students assign functions to each member of the group, the time of each } \\
\text { person, the method of implementation, the means to produce the final } \\
\text { product, which is electric lighting, the model of a bamboo toothpick } \\
\text { house. } \\
\text { - Design PowerPoint slides to report the work of the group. }\end{array}$ \\
\hline
\end{tabular}

Step 8.6.2. Implementation and construction of STEM products (10 periods) (working after school)

Electric lighting design of bamboo toothpick house model based on the design plan:

+ Locate the battery source and the switch on the house model;

+ Identify locations for light bulbs and power lines on the house model (we recommend conducting wires below and behind the model);

+ Drill small holes behind the model (remove the roof and a wall of the model house to install electricity and put back together), wiring and indoor LEDs, mounting switches, connecting the power battery to try on. Then fix switch 1 for electricity inside the house;

+ Wiring and installing lights for trees, led string lights, garden. Install the source to try and fix switch 2 to control the lighting system outside the house model. 


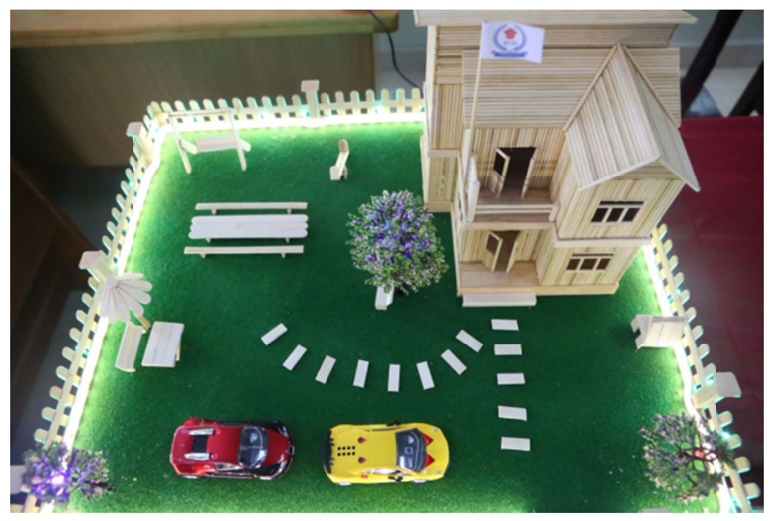

Figure 20. Students of $9+$ College program - Ho Chi Minh City International College have designed to light the house of the bamboo toothpick, Vietnam, 2020 (Personal collection)

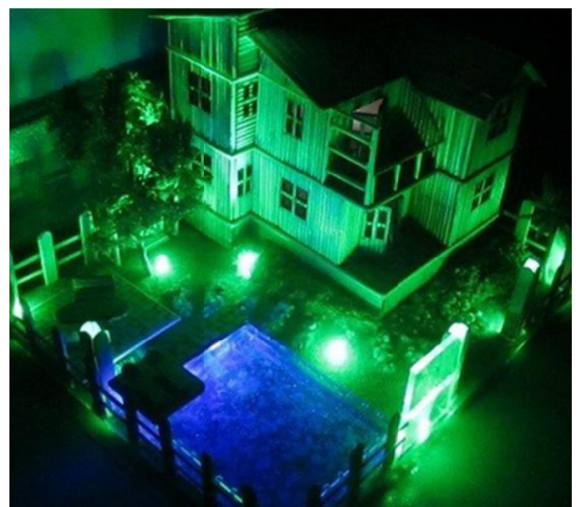

Figure 21. Students of $9+$ College program - Ho Chi Minh City International College have designed to light the house of the bamboo toothpick, Vietnam, 2020 (Personal collection)

Garden decoration:

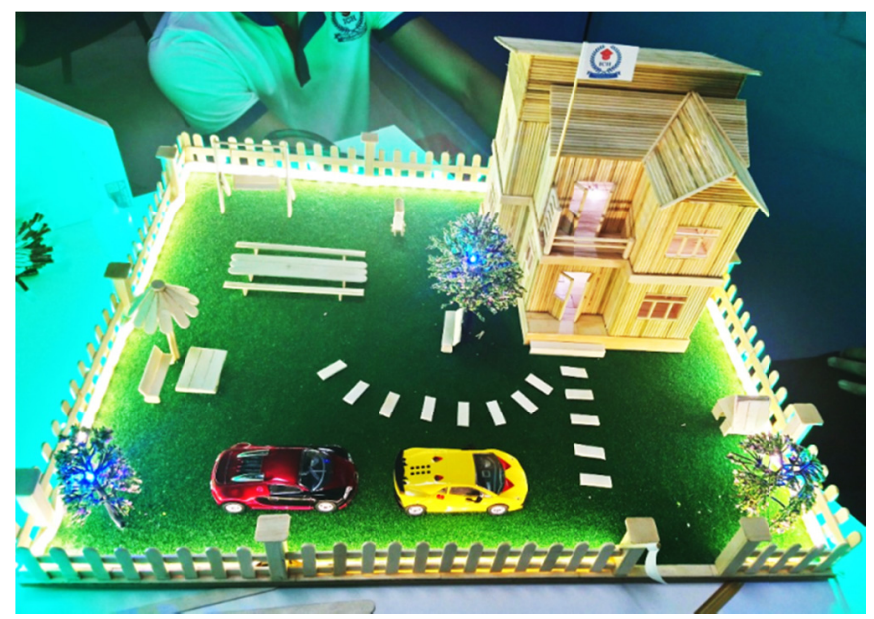

Figure 22. Students of $9+$ College program - Ho Chi Minh City International College have designed to light the house of the bamboo toothpick, Vietnam, 2020 (Personal collection)

Complete the report to prepare the product presentation:

- Students perfect the product;

- Write a description presenting the product: materials, how to make the product, how to operate the product, the applicability of the product;

- Instructors support students in the process of finishing products and preparing reports.

Table 8. Product presentation

\begin{tabular}{|c|c|c|}
\hline \multicolumn{3}{|c|}{ Step 8.6.3. Report results (5 periods) } \\
\hline $\begin{array}{l}\text { Report } \\
\text { results }\end{array}$ & - Let groups report results and feedback. & $\begin{array}{l}\text { - Groups report the results } \\
\text { - PowerPoint presentation } \\
\text { - The groups participate in feedback about the } \\
\text { performance of the other groups. }\end{array}$ \\
\hline Evaluation & $\begin{array}{l}\text { The teacher guides students to self-assess and evaluate each other. } \\
\text { The teacher will then assess the students. }\end{array}$ & $\begin{array}{l}\text { Students use votes to self-assess and evaluate each } \\
\text { other. }\end{array}$ \\
\hline
\end{tabular}


Step 8.7. Design toolkit, test criteria, and student assessment

In addition to the set of criteria for evaluating group and individual activities, we also set up a set of standards for evaluating product design and lighting of a bamboo toothpick house model as follows:

Table 9. Criteria for testing and evaluating students

\begin{tabular}{|c|c|c|c|}
\hline Criteria & Good (5 marks) & Fair (3 marks) & Poor (1 mark) \\
\hline Form & $\begin{array}{l}\text { The lighting installation is } \\
\text { reasonable. The light is on, and } \\
\text { there are enough light bulbs. }\end{array}$ & $\begin{array}{l}\text { Installing lights for some places is } \\
\text { unreasonable. The light is bright, but the } \\
\text { number of light bulbs is a bit much. }\end{array}$ & $\begin{array}{l}\text { Incorrect installation of lights. The } \\
\text { number of bulbs is too much. }\end{array}$ \\
\hline Firmness & Sure model. & The model is not very sure. & Unsure model \\
\hline $\begin{array}{l}\text { Electric } \\
\text { circuit } \\
\text { drawing }\end{array}$ & $\begin{array}{l}\text { Students have completed } \\
\text { electrical design products } \\
\text { according to the drawing. They } \\
\text { can read the drawing. }\end{array}$ & $\begin{array}{l}\text { Students have completed a part of electrical } \\
\text { design products according to the drawing. } \\
\text { Do not know how to read some places on the } \\
\text { drawing. }\end{array}$ & $\begin{array}{l}\text { Students have failed to complete the } \\
\text { electrical design product according to } \\
\text { the drawing, and they are unable to read } \\
\text { the drawing. }\end{array}$ \\
\hline Creativity & $\begin{array}{l}\text { The product is innovative, has a } \\
\text { high practical application. }\end{array}$ & $\begin{array}{l}\text { The product is innovative but still a bit } \\
\text { awkward. }\end{array}$ & The product is molded and not flexible. \\
\hline
\end{tabular}

Some evaluation questions:

Question 1. When designing electric lighting for the model of a bamboo toothpick house, do you find the installation of lights and wires reasonable? Are there too many light bulbs? If so, how would you install it appropriately?

Question 2. Is the model of a bamboo toothpick house safe after installation of lights and wires? If you are not sure, what should you do to make a bamboo house model stronger?

Question 3. Looking at the electrical design drawing of a bamboo toothpick model, can you do the same, and can you design a matchstick house model or an ice cream stick house model?

Question 4. In your opinion, what are the elements of science, technology, engineering, and mathematics in designing and lighting electric models of bamboo toothpick houses? Please fill in the following form.

Table 10. STEM table

\begin{tabular}{l|l}
\hline Full name: $\ldots \ldots \ldots \ldots \ldots \ldots \ldots \ldots \ldots \ldots \ldots \ldots \ldots$ Group: $\ldots \ldots \ldots \ldots$ Class:................ \\
\hline SCIENCE (S) & \\
\hline TECHNOLOGY (T) & \\
\hline ENGINEERING (E) & \\
\hline MATHEMATICS (M) & \\
\hline GENERAL CONCLUSIONS:
\end{tabular}

\section{Discussion}

In Vietnam, no other plant is as abundant and useful as bamboo. They can process bamboo into high-class handicraft products, supply to domestic and foreign markets. Teaching students the topic of STEM-related to bamboo is very helpful. Students will find bamboos more useful. From the design and implementation of the model of a bamboo toothpick house, students will initially get acquainted with construction drawings, house models, which will help in finding a career that suits them. In teaching about the design and implementation of the model of a bamboo toothpick house, the method of problem-based learning is one of the most appropriate teaching methods. This method helps teachers to raise problems for students, help students solve problems, and deepen problems. Also, the practice of problem-based learning helps students work together to perfect the product of a bamboo toothpick house model. After completing the model of a bamboo toothpick house, students think about lighting it up. This approach is a creative way that needs to be encouraged for replication when teaching STEM.

\section{Acknowledgments}

The author thanks Phan Nguyen Loc for his help in the improvement of this paper. 


\section{References}

Allen, P. J., Chang, R., Gorrall, B. K., Waggenspack, L., Fukuda, E., Little, T. D., \& Noam, G. G. (2019). From quality to outcomes: A national study of afterschool STEM programming. International Journal of STEM Education, 6(1), 37. https://doi.org/10.1186/s40594-019-0191-2

Hallström, J., \& Schönborn, K. J. (2019). Models and modelling for authentic STEM education: reinforcing the argument. International Journal of STEM Education, 6(1), 22. https://doi.org/10.1186/s40594-019-0178-z

Hmelo-Silver, C. E. (2004). Problem-based learning: What and How Do Student Learn? Educational Psychology Review, 16(3), 235-266. https://doi.org/10.1023/b:edpr.0000034022.16470.f3

Ho, T. D. (2017). Using Education exercises by problem-based learning approach at universities. Vietnam Education Review, 297, 14-16.

Kurup, P. M., Li, X., Powell, G., \& Brown, M. (2019). Building future primary teachers' capacity in STEM: Based on a platform of beliefs, understandings and intentions. International Journal of STEM Education, 6(1), 10. https://doi.org/10.1186/s40594-019-0164-5

Le, N. S. (2007). Teaching Maths in elementary schools following teaching trend problem-based learning. Vietnam Education Review, 163, 30-33.

Le, X. Q. (2017). Teaching high school technology according to STEM education (Doctoral Thesis in Educational Science, Hanoi National University of Education, Vietnam).

Manly, C. A., Wells, R. S., \& Kommers, S. (2018). The influence of STEM definitions for research on women's college attainment. International journal of STEM education, 5(1), 45. https://doi.org/10.1186/s40594-018-0144-1

Margot, K. C., \& Kettler, T. (2019). Teachers' perception of STEM integration and education: A systematic literature review. International Journal of STEM Education, 6(1), 2. https://doi.org/10.1186/s40594-018-0151-2

Nguyen, B. K. (2004). Methods of teaching Math. Vietnam: Vietnam National University of Education Publishing House.

Nguyen, S. N., Dao, N. C., \& Phan, T. B. L. (2018). Some issues of STEM education in schools meet the new general education curriculum, Journal of Education of Vietnam, 9, 25-29.

Nguyen, T. N., Phung, V. H., Nguyen, Q. L., \& Hoang, P. M. (2017). Designing and organizing STEM education topics for Middle and High School students. Vietnam: Ho Chi Minh City University of Education Publishing House.

Nguyen, T. T. H., \& Tran, Q. B. (2019). Developing scientific research skills of engineering students through problem-based learning, Vietnam Education Review, 4, 234-238.

Pham, V. C. (2011). Creating problem-solving situations in problem-based learning about decimal problems for 5th graders. Journal of Education of Vietnam, 274, 42-44.

Reynders, G., Lantz, J., Ruder, S. M., Stanford, C. L., \& Cole, R. S. (2020). Rubrics to assess critical thinking and information processing in undergraduate STEM courses. International Journal of STEM Education, 7(1), 1-15. https://doi.org/10.1186/s40594-020-00208-5

Seyranian, V., Madva, A., Duong, N., Abramzon, N., Tibbetts, Y., \& Harackiewicz, J. M. (2018). The longitudinal effects of STEM identity and gender on flourishing and achievement in college physics. International journal of STEM education, 5(1), 40. https://doi.org/10.1186/s40594-018-0137-0

Stehle, S. M., \& Peters-Burton, E. E. (2019). Developing student 21 st Century skills in selected exemplary inclusive STEM high schools. International Journal of STEM Education, 6(1), 39. https://doi.org/10.1186/s40594-019-0192-1

Strobel, J., \& Van Barneveld, A. (2009). When is PBL more effective? A meta-synthesis of meta-analyses comparing PBL to conventional classrooms. Interdisciplinary Journal of Problem-based Learning, 3(1), 44-58. https://doi.org/10.7771/1541-5015.1046

Thornburg D. D. (2008). Why STEM Topics are Interrelated: The Importance of Interdisciplinary Studies in K-12 Education. Retrieved from https://docplayer.net/7897206-Why-stem-topics-are-interrelated-the-importance-of-interdisciplinary-studies -in-k-12-education.html 
Tomkin, J. H., Beilstein, S. O., Morphew, J. W., \& Herman, G. L. (2019). Evidence that communities of practice are associated with active learning in large STEM lectures. International Journal of STEM Education, 6(1), 1. https://doi.org/10.1186/s40594-018-0154-z

Tran, T. G., Nguyen, T. P., \& Nguyen, T. H. T. (2018). STEM Education topic design in the teaching "Material and energy metabolism in plants", biology 11 - High school. Journal of Education of Vietnam, 443, 59-64.

Yildiz, S. G., \& Ozdemir, A, S. (2015). A content Analysis Study About Stem Education. The Turkish Online Journal of Educational Technology, 9, 14-21.

Yldirim, B., \& Topalcengiz, E. S. (2018). Stem Pedagogical Content Knowledge Scale (STEMPCK): A Validity and Reliability Study. Journal of STEM Teacher Education, 2(53), 1-20. https://doi.org/10.30707/jste53.2yildirim

\section{Copyrights}

Copyright for this article is retained by the author(s), with first publication rights granted to the journal.

This is an open-access article distributed under the terms and conditions of the Creative Commons Attribution license (http://creativecommons.org/licenses/by/4.0/). 